\title{
ON CONVERGENCE ANALYSIS OF AN ITERATIVE ALGORITHM FOR FINDING COMMON SOLUTION OF GENERALIZED MIXED EQUILIBRIUM PROBLEMS AND FIXED POINT PROBLEMS
}

\author{
D. R. SAHU, N. C. Wong And J. C. YaO
}

\begin{abstract}
The purpose of this paper is to investigate nonemptyness of the solution set for generalized mixed quasi-equilibrium problems and investigate the asymptotic behavior of an iterative algorithm for finding common solution of generalized mixed equilibrium problems and fixed point problems of asymptotically nonexpansive mappings under mild conditions of iteration parameters. Our results improve and extend the recent known results of equilibrium problems, variational inequalities and fixed point theory.
\end{abstract}

Mathematics subject classification (2000): 47H10, 47H15, 47H09, 47H17, 65J15.

Keywords and phrases: $\eta$-strongly monotone, asymptotically nonexpansive mapping, contraction mapping, equilibrium problem, fixed points, generalized set-valued strongly nonlinear mixed variational inequality, iterative methods, KKM-mapping, iterative algorithm.

\section{REFERENCES}

[1] R.P. Agarwal, Donal O'Regan and D.R. SAHu, Iterative construction of fixed points of nearly asymptotically nonexpansive mappings, J. Nonlinear Convex Anal., 8 no. 1 (2007), 61-79.

[2] L.C. CENG AND Q.H. ANSARI, J.C. YAO, Iterative algorithm for solving mixed quasi-variational-like inequalities with skew-symmetric terms in Banach spaces, J. Inequal. Appl., (2006), 1-16.

[3] L.C. CENG AND Q.H. ANSARI, J.C. YAO, Viscosity approximation for generalized equilibrum problems and fixed points, J. Global Optim., (2007), in press.

[4] L.C. CENG AND J.C. YAO, A hybrid iterative shceme for mixed equilibrium problem and fixed point problem, J. Comput. Appl. Math., 214 (2008), 186-201.

[5] C.E. Chidume AND B.Ali, Approximation of common fixed points for finite families of nonself asymptotically nonexpansive mappings in Banach spaces, J. Math. Anal. Appl., 330 no.1 (2007), 377-387.

[6] C.E. Chidume, J. LiU AND A. Udomene, Convergence of paths and approximation of fixed points of asymptotically nonexpansive mappings, Proc. Amer. Math. Soc., 113 (2005), 473-480.

[7] C.E. Chidume, E.U. Ofoedu, H. Zegeye, Strong and weak convergence theorems for asymptotically nonexpansive mappings, J. Math. Anal. Appl., 280 (2003), 364-374.

[8] N.H. DIEn, Some remarks on variational-like and quasivariational-like inequalities. Bull. Austral. Math. Soc. , 46 no. 2, (1992), 335-342.

[9] K. FAN, A generalization of TychonoffŠfs fixed-point theorem, Math. Ann., 142 (1961), 305-310.

[10] S.D. Flam AND A.S. ANTIPIN, Equilibrium programming using proximal-like algorithms, Math. Programming, 78 no. 1, Ser. A (1997), 29-41.

[11] F. FLORES-BAZAN, Existence theorems for generalized noncoercive equilibrium problems: the quasiconvex case, SIAM J. Optim., 11, no.3 (2000), 675-690.

[12] R. Glowinski, J.L. Lions, R. TRemolieres, Numerical Analysis of Variational Inequalities, NorthHolland, Amsterdam, Holland, 1981.

[13] K. GOEBEL AND W.A. KIRK, A fixed point theorem for asymptotically nonexpansive mappings, Proc. Amer. Math. Soc., 35 (1) (1972), 171-174. 
[14] K. GOEBEL AND S. REICH, Uniform convexity, hyperbolic geometry, and nonexpansive mappings, Marcel Dekker, Inc., 1984.

[15] M.A. HANSON, On sufficiency of the Kuhn-Tucker conditions, J. Math. Anal. Appl., 80 no.2, (1981), 545-550.

[16] S.A. HirstoagA, Iterative selection methods for common fixed point problems, J. Math. Anal. Appl. 324 (2006), 1020-1035.

[17] S.H. KHAN AND H. FUKHARUDDIN, Weak and strong convergence of a scheme with errors for two nonexpansive mappings, Nonlinear Analysis, 61 (2005), 1295-1301.

[18] A. MouDAFI, Viscosity approximation methods for fixed points problems, J. Math. Anal. Appl., 241 (1) (2000), 46-55.

[19] S.B. NADLER JR., Multi-valued contraction mappings, Pacific J. Math. 30 (1969) 475ŠV488.

[20] M.A. Noor, Variational-like inequalities, Optimization, 30 no. 4 (1994), 323-330.

[21] M.A. NoOR, Multivalued general equilibrium problems, J. Math. Anal. Appl., 283 (2003) 140-149.

[22] M.O. OsILIKE AND S.C. ANIAGBOSOR, Weak and strong convergence theorems for fixed points of asymptotically nonexpansive mappings, Mathematical and Computer Modelling, 32 (2000), 11811191.

[23] B.E. RHOADES, Fixed point iterations for certain nonlinear mappings, J. Math. Anal. Appl., 183 (1994) 118-120.

[24] J. SCHU, Iterative construction of fixed points of asymptotically nonexpansive mapping, J. Math. Anal. Appl., 159 (1991), 407-413.

[25] J. SCHU, Weak and strong convergence of fixed points of asymptotically nonexpansive maps, Bull. Austral. Math. Soc., 43 (1991), 153-159.

[26] N. SHAHZAD AND A. UDOMENE, Fixed point solutions of variational inequalities for asymptotically nonexpansive mappings in Banach spaces, Nonlinear Anal., 64 no. 3 (2006), 558-567.

[27] S. TAKAHASHI AND W. TAKAHASHI, Viscosity approximation methods for equilibrium problems and fixed point problems in Hilbert spaces, J. Math. Anal. Appl., 331 (2007) 506-515.

[28] K.K. TAN AND H.K. XU, Fixed point iteration process for asymptotically nonexpansive mappings, Proc. Amer. Math. Soc., 122 (1994), 733-739.

[29] H.K. XU, Iterative algorithms for nonlinear operators, J. London Math. Soc. , 66 (2002), 240-256.

[30] L.C. ZENG, S. SCHAIBLE, AND J.C. YAO, Iterative algorithm for generalized set-valued strongly nonlinear mixed variational-like inequalities, J. Optim. Theory Appl., 124 no. 3 (2005), 725-738. 